\title{
ДЕРЖАВНО-ПРИВАТНЕ ПАРТНЕРСТВО ЯК МЕХАНІЗМ УЗГОДЖЕННЯ ІНТЕРЕСІВ СОЦІАЛЬНИХ ГРУП НА РЕГІОНАЛЬНОМУ РІВНІ
}

Малиновська Н.Л., канд. іст. наук. доцент, Інститут державного управління, Чорноморський національний університет імені Петра Могили, м. Миколаїв, Україна

У статті розглянуто сутність державно-приватного партнерства як механізму узгодження інтересів держави $і$ бізнесу з подальшою користю для суспільства в изілому, розкрито можливості застосування цьього інструментарію для реалізації інфраструктурних проектів та надання публічних послуг в Украӥні, розглянуто переваги ДПП, показано сочіальну вагомість та результативність як для громадян, так і для органів державної влади та місиевого самоврядування. Наведено приклади з історії і практики суспільного життя щзодо відстоювання інтересів соціальних груп різними способами й методами (середньовічні гільдії, політичні клуби в період Франиузької револючії, професійні союзи найманих робітників у Новий час, підприємницькі організаџї, страйки щахтарів тощо). Акцентується особлива увага, щзо узгодження інтересів соиіальних груп є історично важливим та необхідним фактором щзодо запобігання виникнення сочіальних викликів та сочіальних непорозумінь. Простежено появу ідеї державно-приватного партнерства та ї̈ сприйняття як органами влади, так і приватним сектором і громадянами. Робиться акцент на тому, щзо укладення партнерського договору між державою та приватною організачією є результатом компромісу між пріоритетом економічної $і$ фінансової ефективності, які є головними для бізнесу, та соџіальними пріоритетами, які є головними для органів державної влади та органів місиевого самоврядування. Наведено приклади державно-приватного партнерства на регіональному рівні - на Півдні Украӥни, показано пере- 
ваги використання механізму державно-приватного партнерства в контексті суспільних інтересів країни та регіону.

Ключові слова: державно-приватне партнерство, інтереси сочіальних груп, органи місцевого самоврядування, сочіалізація бізнесу, регіональний рівень.

Постановка проблеми у загальному вигляді. Узгодження інтересів соціальних груп варто розглядати і як фактор соціальної безпеки, і як фактор соціального розвитку. За своєю природою інтереси соціальних груп є різними, від деяких непорозумінь до повного несприйняття, навіть до ворожого ставлення, що провокує конфлікти, призводить до соціальних викликів та соціальних ризиків. Ситуація ускладнюється і за рахунок регіонального рівня, оскільки людські, природні, промислові та інші ресурси того чи іншого регіону різні, і від того, як вони використовуються, які результати отримують різні соціальні групи, можна говорити про вдале чи не зовсім вдале управління з боку органів місцевого самоврядування. Оскільки сьогоднішнє суспільство визнається не тільки інформаційним, а й комунікативним, пошук механізмів узгодження інтересів має відбуватись мирно й продуктивно. Одним з таких механізмів, на нашу думку, має виступати державно-приватне партнерство на регіональному рівні.

Аналіз досліджень і публікацій. Питання державно-приватного партнерства викликають інтерес як у теоретиків, так і у практиків. Систематизацією науково-методичних підходів щодо трактування поняття «державно-приватне партнерство» займались Л. Гриценко, М. Солодаренко, теоретичні та регуляторно-інституціональні основи ДПП досліджували Л. Руденко-Сударєва, О. Мозговий, К. Пашинська; зарубіжний досвід ДПП та можливості його використання для України висвітлюється у працях Г. Панікар, М. Лендьел, Б. Винницький, Ю. Ратейчак, І. Санжаровський; державно-приватне партнерство як форма взаємодії влади та бізнесу є предметом уваги таких науковців, як Т. Пахомова, Н. Піроженко. Треба зазначити, що більшість праць розглядають питання державно-приватного партнерства з точки зору правового, економічного та організаційного забезпечення, питання соціального значення ДПП залишається менш дослідженим. 
Формулювання цілей статті (постановка завдання). В процесі дослідження було поставлено наступні завдання:

- дослідити інтереси соціальних груп на предмет існуючих та потенційних протиріч;

- розглянути державно-приватне партнерство як альтернативне фінансування суспільно важливих проектів;

- запропонувати державно-приватне партнерство як механізм для узгодження інтересів держави і бізнесу з подальшою користю для суспільства в цілому.

Виклад основного матеріалу дослідження. Узгодження інтересів соціальних груп $\epsilon$ історично важливим фактором щодо запобігання виникнення соціальних ризиків. Відомо, що інтереси різняться за сферою спрямованості: державні, політичні, економічні, духовні; вони можуть бути реальними та уявними; можуть мати прогресивний, регресивний чи консервативний характер тощо. Але саме інтереси об'єднують людей, спонукають їх до дій.

Загальні інтереси кожної з груп залежать від того, який стан посідає іiі член у виробництві, суспільному, релігійному житті тощо. За різних часів історії ті чи інші групи виступали як активні учасники подій, були рушійною силою (повстання рабів, боротьба «третього стану» проти монархії, національно-визвольні рухи, релігійні війни та інші факти). 3 історії і практики суспільного життя можна навести багато прикладів щодо відстоювання інтересів соціальних груп різними способами й методами (середньовічні гільдії, політичні клуби в період Французької революції, професійні союзи найманих робітників у Новий час, підприємницькі організації, страйки шахтарів тощо).

У сучасних умовах спробуємо розглянути державно-приватне партнерство (ДПП) як дієвий механізм узгодження інтересів соціальних груп на регіональному рівні, розглянути переваги ДПП, показати соціальну вагомість та результативність як для громадян, так і для органів державної влади та місцевого самоврядування.

Нагадаймо, що інтереси — це об’єктивні відносини між потребами й середовищем, у якому потреби реалізуються внаслідок певної діяльності. Розглядаючи механізм узгодження інтересів соціальних груп, варто розрізняти поняття «суспільний інтерес» та 
«соціальний інтерес». Суспільний інтерес характеризується наявністю спонукальної сили діяльності соціальних груп, мас людей, що дає можливість суспільству здійснювати управлінський вплив на цю діяльність. Соціальний інтерес спрямований на соціальні інститути, установи, норми взаємовідносин у суспільстві, від яких залежить розподіл предметів, цінностей і благ, що забезпечують задоволення потреб.

При аналізі суспільних інтересів обов'язково треба звертати увагу на категорію суспільних потреб. Потреби як спосіб реалізації суспільних відносин становлять іманентну сутність особистості, а інтереси виступають зовнішнім проявом суспільних відносин. Зміст інтересів формується на основі як потреб, так і соціальних засобів, залучених до їх реалізації [23].

Людина задовольняє потреби лише в суспільстві, інтереси реалізуються тоді, коли вирішуються протиріччя, які виникають внаслідок різних потреб різних соціальних верств і груп. Інтереси мають об'єктивний характер, тому одним із суттєвих питань $\epsilon$ їх усвідомлення. Успішність реалізації інтересів різних соціальних груп пов'язана 3 мірою їх усвідомлення. Якщо об'єктивні інтереси не усвідомлено або усвідомлено хибно, будь-яка соціальна група може або досягти мети, що об'єктивно не відповідає іiі інтересам, або взагалі не прагнути вигідного для себе рішення.

Усвідомлення інтересів передбачає також їх диференціацію на поточні й фундаментальні. Перші відображають умови існування суб'єкта, пов'язані з задоволенням елементарних потреб; другі тісно пов'язані з основними умовами існування індивіда, з суттю цього соціально-економічного ладу.

Групи інтересів та групи тиску існують впродовж усієї історії людства, відтоді, коли почали формуватися системи влади. Специфіка конкретної групи інтересів виявляється в тому, що, по-перше, саме конкретний інтерес відрізняє цю групу від інших суб'єктів господарської діяльності; по-друге, ці інтереси можуть виходити за межі норм, правил, навіть закону; по-третє, вони повинні мати можливість представити свої прагнення державним структурам. Специфіка інтересу є однією з базових ознак групи. 
Ускладнення структури суспільства відображається у складній конфігурації різноманітних групових інтересів, громадських потреб та шляхів їх вирішення.

Ситуація є неоднозначною і за рахунок регіонального рівня. Можливості того чи іншого регіону мають свої особливості, певні людські, природні, промислові та інші ресурси, і від того, як вони використовуються, які результати отримують різні соціальні групи залежить оцінка діяльності органів місцевого самоврядування. В умовах науково-технічного прогресу, в час інформаційно-комунікативних технологій, коли йдуть постійні розмови про соціалізацію бізнесу, про загальнолюдські цінності та інші гуманістичні підходи до вирішення соціальних проблем, пошук механізмів узгодження інтересів має відбуватись мирно й продуктивно. Одним 3 таких механізмів, на нашу думку, має виступати державно-приватне партнерство на регіональному рівні.

В літературі наводяться приклади державно-приватного партнерства як в давні часи, так і недалекого минулого. Звичайно, що це лише елементи ДПП, але сама ідея перевірена часом і заслуговує уваги. У 1887 році між Паризьким муніципалітетом та Гюставом Ейфелем був підписаний договір на експлуатацію земельної ділянки в центрі міста на 25 років. Також цей договір передбачав співфінансування: 25 \% - муніципалітет, решта - це кошти Гюстава Ейфеля. Наступного року, 1888, була створена спеціальна компанія 3 уставним капіталом в 5 млн. франків, 3 них 50 \% Ейфеля, 50 \% - 3 банки. Загальна вартість будівництва склала 7,8 млн. франків, які компенсувалися вже протягом роботи виставки 3 нагоди відкриття вежі завдяки екскурсіям, сувенірам тощо [2, 11, 23].

В нових умовах регіональної політики в Україні з'явилась можливість на основі державно-приватного партнерства залучити приватний капітал для вирішення невідкладних і нагальних питань, пов'язаних із задоволенням громадських потреб. Інфраструктура, що існує, знаходиться у поганому стані або ж перевищила терміни експлуатації, планові терміни служби і є не здатною функціонувати на рівні, як того вимагає забезпечення конкурентоспроможності країни. 
Не зупиняючись на причинах появи державно-приватного партнерства, нагадаємо лише схематично, чому ця ідея взагалі виникла і як сприймається та реалізується в світі і в Україні, і чому саме на державно-приватне партнерство покладаються такі надії.

Упродовж другої половини XX століття у багатьох країнах органи влади були вимушені вирішувати близькі за характером фіскальні проблеми. Розвиток суспільств і ринків неминуче призвів до зростання попиту населення на громадські послуги, а, отже, до збільшення відповідних бюджетних видатків. Довгий час органи влади задовольняли попит населення за допомогою традиційного інструментарію, а саме: збільшення обсягу бюджетних надходжень шляхом збільшення обсягів чи бази оподаткування. Однак, наприкінці минулого століття комплекс чинників - стрімке зростання державного дефіциту, поглиблення глобалізації, протести громадськості щодо зростання податків - позбавив уряди можливості збільшувати надходження до відповідних бюджетів. Така перешкода стала поштовхом до пошуку нових моделей фінансування громадських послуг і публічної інфраструктури [2].

На початку 1990-х років стало зрозумілим, що держава не може використовувати механізм приватизації для підвищення ефективності використання чи розвитку інфраструктури, яка традиційно $\epsilon$ монополією держави і з правової та політичної позицій не може бути передана у власність бізнесу [2].

В першу чергу, це стосувалось соціальної інфраструктури (лікарні, школи, дитячі садки), стратегічні об'єкти (авто- і залізничні магістралі, газо- і нафтопроводи), комунальні об'єкти (водогони, теплоцентралі, місцеві дороги). У багатьох країнах світу сильну опозицію щодо можливості приватизації цих об'єктів сформували профспілки. В літературі наводяться факти, що в деяких країнах, де були здійснені прецеденти приватизації базової інфраструктури, наприклад, у регіоні Південної Америки, неефективна державна монополія була замінена на більш успішну приватну монополію, вартість послуг якої, крім того, зросла [2].

Саме тоді почав стрімко збільшуватися інтерес до ідеї державно-приватного партнерства (ДПП). ДПП виникло як механізм забез- 
печення доступу до капіталу і досвіду управління у приватному секторі з метою їх застосування у сферах, які є традиційно державними монополіями: громадські послуги і утримання та розвиток інфраструктури. Відповідно до очікувань, ДПП мало досягти успіху там, де приватизація зазнала невдачі; крім того, партнерство сприймали як альтернативу приватизації в тих випадках, коли через різні перешкоди було неможливо іiі провести.

Перші прецеденти укладання ДПП сприймалися як одноразові акції, які не будуть мати повторення після покращення фінансового стану органів влади. Однак, у 1992 році консервативний уряд Дж. Мейджора в Об'єднаному королівстві Великої Британії та Північної Ірландії запровадив Ініціативу приватного фінансування (Private Finance Initiative), яка стала першою систематизованою програмою, спрямованою на заохочення ДПП, зокрема у сфері надання позик приватним секторам урядових структур. Партнерство почало сприйматися як оптимальний механізм залучення органами влади фінансових ресурсів та управлінських навичок бізнесу для надання громадських послуг населенню та розвитку інфраструктури без втрати власності та контролю за цими процесами.

У 1990-х роках, стали помітними перші перешкоди, які заважали поширенню практики укладання партнерства. У деяких випадках рушійними силами впровадження ДПП були не лише прагнення підвищити економічну і соціальну ефективність, але й бажання вивести державні інвестиції із сфери бюджетного та громадського контролю. Наслідком цього стало формування у багатьох регіонах світу організованого супротиву ДПП з боку профспілок, які використовували вплив на громадськість і механізм судових позовів для заборони на національному рівні можливості започаткування проектів на засадах державно-приватного партнерства. Профспілки переконували громадськість, що впровадження державно-приватного партнерства приведе до зменшення кількості робочих місць у бюджетній сфері, що, без сумніву, було вагомим аргументом для працівників галузі публічного [7].

Окрім того, в рамках приватних інфраструктурних проектів послуги населенню надавалися за значно вищою ціною, ніж якби було 
використано процедуру тендеру серед потенційних виконавців замовлень органів влади.

Пріоритетним завданням для приватних інвесторів було швидке повернення вкладених коштів, незважаючи на те, що урядові структури гарантували їх фінансові ризики.

Способом подолання цього бар'єру було запровадження формальних процедур оцінки ДПП, основним критерієм якої була «вартість грошей» (Money value), що вимірювалася досягнутим розподілом фінансового ризику між органом влади (замовником) i приватною компанією (виконавцем).

Незважаючи на перешкоди, практика формування державноприватного партнерства поширюється у всіх регіонах світу. Фундаментальною причиною, яка веде до утворення партнерства, є усвідомлення факту, що приватний і публічний сектори мають унікальні характеристики, які забезпечують їм перевагу у наданні послуг населенню. Іншою засадничою передумовою формування і поширення практики партнерства була зміна підходу до розуміння функцій урядів, зокрема усвідомлення необхідності передачі частини їх приватному сектору як більш мобільному й ефективному.

Отже, державно-приватне партнерство розглядається як довгострокове співробітництво, засноване на договорі між державою (державними органами та органами місцевого самоврядування), а також приватними компаніями, спрямоване на фінансування, проектування, впровадження та управління публічними об'єктами i публічними послугами (public facilities an public services), які традиційно забезпечуються державою (публічним сектором) [2].

Законом України «Про державно-приватне партнерство» ч. 2 ст. 4 визначено сфери реалізації ДПП, але перелік сфер діяльності не $\epsilon$ вичерпним, оскільки за рішенням державного партнера ДПП може застосовуватися в інших сферах діяльності, крім видів господарської діяльності, які відповідно до закону дозволяється здійснювати виключно державним підприємствам, установам та організаціям. Результати сумлінної діяльності на основі ДПП у всіх сферах людської діяльності за визначенням мають позитивний соціальний ефект [15]. 
Отже, державно-приватне партнерство (публічно-приватне партнерство) - це система відносин між органом публічної влади (управління) та приватною організацією, у яких приватній організації надається більша роль у плануванні, фінансуванні та реалізації певної послуги для населення, аніж при використанні традиційних процедур співпраці (наприклад, тендеру), і менше, аніж при використанні механізму приватизації. При цьому захист державних i комунальних інтересів гарантується через інституційні основи, положення нормативних актів та укладених договорів $[4,15]$.

Згідно з визначенням Європейської комісії, запропонованим у 2003 році, державно-приватне партнерство можна охарактеризувати як передання приватному сектору частини повноважень, відповідальності та ризиків щодо реалізації інвестиційних проектів, які традиційно впроваджувалися чи фінансувалися публічним сектором.

Найбільш поширеним $є$ визначення державно-приватного партнерства як такої системи співробітництва, у якій розподіляються ризики між партнерами за принципом кращої спроможності їх нейтралізувати, а також існує узгоджений підхід до поділу винагород.

На початку XXI століття стало очевидним, що ДПП є однією 3 найбільш ефективних форм співробітництва між публічним і приватним секторами. Ця співпраця заснована на визнанні факту, що обидві сторони отримують вигоди від об'єднання фінансових ресурсів, технологій і управлінських знань заради підвищення рівня послуг для громадян.

До основних переваг державно-приватного партнерства фахівці відносять наступні:

- фінансові вигоди для органів державної влади та органів місцевого самоврядування, соціально-економічні вигоди для територіальної громади, а також політичні переваги;

- рентабельні проекти державно-приватного партнерства можуть виступати джерелом надходження нових фінансових ресурсів завдяки розподілу прибутку між приватним оператором (партнером) та органами влади/органами місцевого самоврядування. Таким чином, проект може реалізовуватись, не створюючи тягаря для бюджету, а вивільнені бюджетні ресурси можуть спрямовуватись на інші 
цілі, такі як охорона здоров'я, освіта, та інші соціальні проекти;

- прискорена реалізація проектів дозволяє швидше отримати ефект для громади від впровадження нових послуг чи підвищення якості існуючих та сприятиме збільшенню приватних інвестицій та економічному розвитку регіону;

- державно-приватне партнерство змінює роль уповноважених органів державної влади/органів місцевого самоврядування 3 органу, який володіє та експлуатує, в орган, який адмініструє і контролює. Це дозволяє державним органам влади та органам місцевого самоврядування підвищити рівень якості державних і комунальних послуг, зменшивши при цьому видатки державного/місцевого бюджету, у т.ч. витрати людських ресурсів на надання цих послуг.[2].

Окрім того, ДПП є альтернативою приватизації об'єктів державної та комунальної власності, оскільки об'єднує переваги публічного та приватного секторів, зокрема такі: соціальну відповідальність, громадську підзвітність і пріоритетність екологічних стандартів у діяльності, що є притаманною для державних і комунальних організацій; фінансові ресурси, технології, управлінську ефективність і підприємницький дух приватного сектору.

За даними центральних та місцевих органів виконавчої влади в Україні станом на 01.01.2017 року на засадах ДПП реалізується 186 проектів1 (укладено 153 договорів концесії, 32 договори про спільну діяльність, 1 договір державно-приватного партнерства). Понад 60 \% проектів ДПП від загальної кількості було реалізовано в сфері оброблення відходів, 20 \% у сфері збору, очищення та розподілення води, понад 8 \% в сфері інфраструктури та понад 3 \% в сфері виробництва, транспортування і постачання тепла [3].

Найбільш серйозною перешкодою на шляху реалізації проектів ДПП є загальний стан інституційного середовища, в якому приватному партнеру доводиться реалізовувати проект ДПП. До найбільш серйозних проблем системного характеру варто віднести: труднощі 3 отриманням дозвільних документів та погоджень, що необхідні для реалізації проекту ДПП; складність в переоформленні на приватного партнера права користування земельною ділянкою, на якій розташований об'єкт ДПП; недостатня фахова підготовка посадо- 
вих осіб, які займаються питаннями ДПП, низький рівень їх мотивації; наявність корупційних проявів; складність практичної реалізації гарантій, що надаються державним партнером для цілей реалізації проекту ДПП тощо.

Фахівці зазначають, що під час застосування законодавства про ДПП на практиці виникає значна кількість проблемних моментів. Водночас, варто підкреслити, що більшість цих проблем стосується проектів, що реалізуються на державному рівні за участю центральних органів виконавчої влади (понад 80\%). Для проектів, що реалізуються на місцевому рівні за участю органів місцевого самоврядування, існує набагато менше перешкод, оскільки практично відсутня необхідність погодження таких проектів з іншими державними органами, що потенційно може сприяти розвитку державноприватного партнерства на регіональному рівні.

За даним ряду досліджень, в ЄС щороку реалізується велика кількість проектів ДПП. За даними Європейського центру експертизи у сфері ДПП, у 2016 році в СС було реалізовано майже 60 проектів ДПП загальною вартістю 12 млрд. євро. Більшість проектів ДПП в СС було реалізовано в наступних сферах: транспорт - $31 \%$, медицина - $19 \%$, освіта - 13 \%, телекомунікації - 10 \%. Найбільш успішними проектами ДПП в зарубіжних країнах на місцевому рівні є проекти водопостачання та водовідведення (Чилі, Вірменія), управління твердими побутовими відходами (Канада), будівництво житла (Польща та Великобританія), вуличне освітлення (Великобританія). В Україні найбільш успішними проектами ДПП є проекти в сфері виробництва та постачання теплової енергії (м. Малин, м. Остер).

Завдання, які розв'язуються за допомогою державно-приватного партнерства, можна узагальнити таким чином:

- дає змогу органам влади зосередитись на основних функціональних питаннях. Основна роль органів влади полягає в просуванні інтересів громадськості шляхом упровадження дієвої політики. Коли приватний сектор бере на себе відповідальність за другорядні, неосновні функції, це дає змогу владі перерозподілити свої ресурси й зосередитись на виконанні своєї основної ролі; 
- сприяє поліпшенню управління державними активами Традиційні цикли планування закупівель часто базуються на короткотерміновій перспективі, внаслідок чого утримання та відновлювання активів часто буває неоптимальним. 3 іншого боку, приватний сектор застосовує до планування та бюджетування підхід 3 позицій «життєвого циклу», використовуючи довготермінові контракти. До цих контрактів включають кошти для утримання, що гарантує збереження активів у доброму стані та належний догляд за ними.

- сприяє підвищенню якості надання послуг унаслідок упровадження інновацій Залучення приватного сектору на конкурентних конкурсних засадах сприяє виробленню ним творчих рішень у сфері створення інфраструктури, планування, будівництва й управління активами.

- дає змогу перекласти ризик із платників податків на приватний сектор. Завдяки такому підходу ризики, пов'язані із несподіваними витратами перевитратами, затримками із виконанням і відхиленнями від календарного графіка й необхідністю реагування на коливання попиту на послуги, дієвим чином перекладаються 3 державного сектору на приватний $[3,4,10,15]$.

Зазначимо, що впровадження та використання механізму ДПП в Україні починається з 2010 року, з прийняттям Закону України «Про державно-приватне партнерство» від 1 липня 2010 року № 2404-VI. [15].

Джерельною базою дослідження стали офіційні сайти органів державної влади і органів місцевого самоврядування; інформаційні ресурси, доступні в мережі Internet; нормативно-правові документи Свропейського Союзу, які розміщені на офіційних сторінках в мережі Internet (наприклад, https://curia.europa.eu/); аналітичні матеріали, розміщені в мережі Internet на офіційних сторінках офісів 3 реалізації проектів ДПП, які створені та діють з метою розширення сфери використання механізму ДПП у різних сферах; методичні та практичні рекомендації з питань впровадження проектів ДПП, які розроблені за ініціативи та підтримки міжнародних фінансових організацій з метою сприяння поширенню такого механізму співпраці приватного та публічного секторів. 
Дані щодо проектів ДПП, які реалізуються в Україні було отримано з інформаційних джерел Міністерства економічного розвитку і торгівлі України, яке відповідно до покладених на нього законодавством завдань проводить моніторинг ефективності діяльності органів виконавчої влади та ОМС у сфері ДПП; організовує перевірки виконання договорів, укладених у рамках ДПП; проводить моніторинг, узагальнення та оприлюднення в установленому порядку результатів здійснення ДПП, у тому числі оцінку та моніторинг загального рівня ризиків державного партнера в договорах, укладених у рамках ДПП; проводить моніторинг дотримання вимог законодавства у сфері ДПП, у тому числі під час проведення конкурсів 3 визначення приватного партнера.

Як показує попередній досвід співпраці держави з приватними партнерами, існує висока ймовірність невиконання зобов'язань 3 боку інвесторів. Зокрема Голова Проектного офісу SP3ILNO Юрій Гусєв наводить приклад нереалізованої концесії з будівництва автомагістралі Одеса - Броди у 2002 році. У 2007 році приватні інвестори недотримали зобов'язань на суму 2,7 млрд грн, тобто 79 \%. Саме для реалізації конкретних пілотних проектів при Міністерстві інфраструктури України, за підтримки Фонду WNISEF, створили Проектний офіс SP3ILNO [3, 10].

Інструмент концесії відповідно до міжнародного досвіду є найефективнішим механізмом залучення інвесторів до інфраструктури. Таку думку поділяють міжнародні партнери України - СБРР, Світовий Банк, WNISEF та інші. Завдяки механізму ДПП існує можливість використати досвід приватних компаній в управлінні державним майном та створити нову інфраструктуру без залучення значних інвестицій з державного бюджету. Цей механізм дозволяє підвищити ефективність роботи не лише окремих об'єктів інфраструктури чи підприємств, але й усієї системи логістики України в цілому.

Приклади державно-приватного партнерства на регіональному рівні. Як зазначає Юрій Гусєв, із 185 проектів, що реалізуються у рамках державно-приватного партнерства в Україні, лише 16 - у сфері інфраструктури. Враховуючи ще й те, що потенціал державних морських підприємств є недостатньо реалізованим через брак інвес- 
тицій та низьку ефективність державного управління, у концесію вирішили передати три інфраструктурні об'єкти - ДП «Стивідорна компанія «Ольвія» у Миколаєві, залізничний поромний термінал у ДП «Морський торговельний порт «Чорноморськ» та ДП «Херсонський морський торговельний порт» у Херсоні. За результатами попередньої оцінки, усі ці проекти викликають зацікавленість із боку як українських, так і міжнародних приватних компаній. Загалом їх реалізація передбачає залучення до 300 млн доларів інвестицій у модернізацію наявної інфраструктури та побудову нової $[3,10]$.

Перевагою стивідорної компанії «Ольвія», активи якої передаватимуться в концесію, $є$ значні вільні площі, доступні для подальшого розширення порту та розвитку припортового виробництва. «Ольвія» розташована в Корабельному районі Миколаєва в Бузькому лимані за 30 км від Чорного моря. Порт є диверсифікованим, структура вантажообігу майже рівномірно розподілена між зерном, металами та глиною (близько 30 \% кожен).

Передовсім необхідно реалізувати потенціал екстенсивного розвитку порту та будівництва нової інфраструктури на вільних ділянках, підвищити вантажообіг й відповідно збільшити частку на ринку (нині вона складає 5\% при вантажообігу 2,2 млн т.). Після проведення попереднього ТЕО вдалося виявити і деякі проблемні сфери. Зокрема багато років невирішеним є питання автомобільного сполучення із портом: місцева влада досі не реалізувала проект із будівництва 24 км об'їзної дороги навколо Миколаєва. Також існує проблема із залізничним сполученням: пропускна здатність залізничної станції «Жовтнева» $є$ досить обмеженою, тому також потребує модернізації.

Як зазначає Проектний менеджер SP3ILNO Тарас Бойчук, порт $\epsilon$ універсальним, має 7 причалів довжиною понад 1,5 км, що робить його привабливим для потенційних інвесторів. Тому стоїть завдання оновити інфраструктуру і підвищити ефективність використання наявних об’єктів. Враховуючи географічне розташування порту та промислові потужності, що вже існують у Миколаєві, завданням майбутніх приватних партнерів буде створити в зоні порту кластер із переробки вантажів [3]. 
Не менш важливою є і соціальна сторона проекту, оскільки планується не лише збереження наявного рівня заробітної плати, але і iï можливе зростання за успішної реалізації проекту. Внаслідок модернізації операційних потужностей порту зменшиться екологічна напруга та підвищиться безпека праці на підприємстві. Загалом проект концесії дозволить пожвавити перевезення вантажів, що позитивно вплине на розвиток економіки регіону та суміжних галузей.

Характерною особливістю наступного проекту, а саме залізнично-поромного комплексу Морського торговельного порту «Чорноморськ», є низька операційна ефективність та значний нереалізований потенціал. За словами Юрія Гусєва, інвестиційна привабливість проекту є високою: ринкова частка терміналу складає 71 \% внутрішнього ринку перевезень вантажівок та 95 \% перевезень вантажних вагонів.

Як і у випадку з «Ольвією», одним із ключових завдань інвесторів $\epsilon$ підвищення ефективності роботи терміналу. Проектний менеджер SP3ILNO Tарас Бойчук стверджує, що нині за вантажообігом 1,8 млн тон на рік потужність порту використовується лише на 40 \%, при цьому операційна рентабельність його роботи за 2016 рік склала 41 \%. За результатами попередньої оцінки, мета проекту полягає у збільшенні вантажообігу до 3,5 млн тон на рік. Важливими для успішної реалізації проекту є можливість застосування наявних знижок, нових портових зборів, підписання угод із Грузією та запуск проекту «Шовкового шляху», які суттєво впливають на завантаженість терміналу.

Налагодження ефективної роботи разом із модернізацією виробничих потужностей та впровадженням додаткових послуг сприятимуть тому, що «Чорноморськ» поступово нарощуватиме вантажообіг, відвойовуючи частку ринку поромних перевезень не лише у портів України, але й Румунії та Болгарії.

Особливістю наступного об'єкту концесії, а саме Херсонського морського торговельного порту, є можливість створити на його базі мультимодальний транспортний хаб при перевезенні вантажів між Чорним морем та Дніпром. Водночас максимальна глибина порту $є$ невеликою (7,6 м), а обладнання зношене на 90 \%, що створює необхідність додаткових інвестицій в оновлення порту. 
Попередня оцінка виявила й інші проблеми, що характеризують роботу та нинішній стан Херсонського порту. За словами Проектного менеджера SP3ILNO Артема Хорошуна, очевидною є необхідність підвищення ефективності роботи підприємства: при доходах у 7,9 млн доларів за 2016 рік операційна рентабельність склала лише 14\%, наявні обмежені площі порту використовуються неефективно. Внаслідок зношеності усього обладнання перед інвесторами постане необхідність капітальних інвестицій у проект, що складатимуть від 25 до 45 млн доларів. Слід зазначити, що концесія може бути привабливою для виробників сільськогосподарської продукції, оскільки основну частку вантажопотоку за прогнозами складатимуть зернові, а також для портових операторів, що віддають перевагу змішаним портам із різними видами вантажів.

Важливим для зростання вантажообігу порту є збільшення судноплавства на Дніпрі, яке може значно підвищити привабливість створення якісної інфраструктури у ХМТП. Створення транспортного хабу на базі Херсонського порту може суттєво зменшити не лише час транспортування продукції, але й значно знизити транспортні витрати, цим самим здешевлюючи собівартість продукції [3].

Отже, на відміну від традиційних способів створення й утримання інфраструктури, державно-приватне партнерство передбачає розподіл відповідальності, винагороди і ризику між державним і приватним секторами. Більшість проектів, здійснених у рамках ДПП, розпочинаються із визначення ризиків, а також їх розподілу між державним чи приватним секторами, або ж між обома секторами одночасно. Передбачається, що завдяки подібному розподілу ризиків може бути досягнута головна мета партнерських проектів, а саме - надання послуг найвищої якості.

Однак зауважимо, що навіть сьогодні ДПП сприймається лише як додатковий і доповнюючий інструмент, який можна використати для потреб надання громадських послуг і розвитку інфраструктури.

Чинне європейське законодавство безпосередньо не регулює державно-приватне партнерство. Однак загальні принципи, встановленні Угодою про європейські співтовариства, зокрема положення про свободу створення юридичних осіб та надання послуг, 
а також нормативно-правові акти про публічні тендери та концесії, створюють правові засади для формування ДПП. Так, Угода про європейське співтовариство визначає, що усі контракти, враховуючи контракти між державною та приватною організацією, повинні відповідати принципам прозорості, неупередженості, пропорційності та взаємного визнання. На практиці це означає, що створення партнерства не повинно мати негативний вплив на функціонування вільного ринку послуг, а також повинно бути засновано на принципах чесного відбору приватного партнера державою чи місцевим самоврядуванням.

Висновки. Підсумовуючи викладений матеріал доцільно зазначити, що державно-приватне партнерство успішно впроваджується практично в усіх галузях економіки і сферах суспільства. В рамках ДПП реалізовуються проекти з будівництва й утримання шкіл, доріг, мостів, лікарень, інфраструктури водопостачання, водовідведення і електропостачання, аеропортів, громадського транспорту і всіх інших ключових компонентів сучасної цивілізації. Для того, щоб створити середовище, в якому потенціал ДПП може бути якнайповніше використаним, важливо, щоб орган влади, який має намір започаткувати партнерство, розумів справжні мотиви, що спонукають приватні структури до участі у реалізації публічних проектів.

Треба підкреслити, що за допомогою державно-приватного партнерства Україна може залучити приватний капітал для вирішення невідкладних і нагальних питань, пов'язаних із задоволенням громадських потреб, що само по собі вже буде сприяти узгодженню інтересів соціальних груп.

Без сумніву. вивчення та поширення досвіду країн, де активно впроваджуються проекти в рамках державно-приватного партнерства допоможе створити сприятливе середовище для розвитку ДПП, зокрема щодо забезпечення стандартів їх функціонування, враховуючи підзвітність перед владою та громадськістю.

Бажано враховувати думки фахівців Європейського Союзу, які вважають, що у випадку ініціювання державно-приватного партнерства органи влади повинні бути готовими до вирішення основної проблеми управління, а саме: створення відповідних стимулів 
для приватної компанії для належного вироблення бажаного для органу влади продукту - роботи чи послуги. Таким чином, укладення партнерського договору між державною та приватною організацією $\epsilon$ результатом компромісу між пріоритетом економічної і фінансової ефективності, які є головними для бізнесу, та соціальними пріоритетами, які є головними для органів державної влади та органів місцевого самоврядування.

\section{Стаття надійшла до редакціi: 06.03.2019}

\section{PUBLIC-PRIVATE PARTNERSHIP AS A MECHANISM OF DEVELOPING INTERESTS OF SOCIAL GROUPS AT THE REGIONAL LEVEL}

Natalia Malynovska, $\mathrm{PhD}$ in Historical Sciences, Associate Professor at the Department of Social Work, Management and Pedagogy, Institute of Public Administration, Petro Mohyla Black Sea National University, Mykolaiv, Ukraine

The article discusses the essence of public-private partnership as a mechanism for reconciling the interests of the state and business with subsequent benefits to society as a whole, discloses the possibilities of using this tool for the implementation of infrastructure projects and the provision of public services in Ukraine, considering the advantages of PPPs, showing social importance and effectiveness both for citizens, and for state authorities and local self-government bodies.

Examples from the history and practice of social life for defending the interests of social groups in various ways and methods (medieval guilds, political clubs during the French Revolution, professional unions of hired workers in the New Age, entrepreneurial organizations, miners' strikes, etc.) are given.

Particular attention is paid to the fact that the harmonization of interests of social groups is historically important and necessary factors in preventing an emergence of social challenges and social misunderstandings. Harmonization of the interests of social groups should 
be considered both as a factor of social security and as a factor of social development. By its nature, the interests of social groups are different, from some misunderstandings to a general rejection, even to a hostile attitude that provokes conflicts and leads to social challenges and social risks. The situation is also difficult due to differences that exist at a regional level, since the opportunities of one region or another have different human, natural, industrial and other resources. Therefore, depending on how the resources are used, and on the results which are received by different social groups, we can talk about the successful or not quite successful management of the parties of local self-government. Since today's society is acknowledged not only informational but also communicative, the search for mechanisms of harmonization of interests should be peaceful and productive. One of such mechanisms, in the opinion of the author, should be public-private partnership at the regional level.

The emergence of the idea of public-private partnership and its perception as authorities, private sector and citizens is outlined. Despite the obstacles, the practice of public-private partnership is spreading in all regions of the world. The fundamental reason for building partnerships is the realization that private and public sectors have unique characteristics that give them the advantage of providing services to the population. Another fundamental prerequisite for the formation and dissemination of the partnership practice was the change in approach to understanding the functions of governments. In particular, the awareness of the need in transferring a part of government functions to a private sector, as more mobile and efficient. Thus, public-private partnerships are considered as long-term cooperation based on an agreement between the state (state and local governments) and private companies, aimed at financing, designing, implementing and managing public facilities and public services, which are traditionally provided by the state (public sector).

Attention is drawn to the fact that, unlike traditional ways of creating and maintaining infrastructure, public-private partnership involves the sharing of responsibilities, rewards and risks between the public and private sectors. Most PPP projects start with the definition of risks, as well as their distribution between the public or private sectors, or between the two sectors at the same time. It is assumed that due to such 
a distribution of risks, the main goal of the partnership projects, namely, the provision of the highest quality services, can be achieved.

It is noted that the current European legislation does not directly regulate public-private partnership. However, the general principles established by the Agreement on European Communities, in particular provisions on the freedom of establishment of legal persons and the provision of services, as well as legal acts on public tenders and concessions, create the legal basis for the formation of PPP. So, the European Community Agreement stipulates that all contracts, including public-private partnerships, must comply with the principles of transparency, impartiality, proportionality and mutual recognition. In practice, this means that the creation of partnerships should not have a negative impact on the functioning of the free market of services and should be based on the principles of the honest selection of a private partner by the state or local government.

The emphasis is placed on the fact that an authorization of a partnership agreement between the state and a private organization is the result of a compromise between the priority of economic and financial efficiency that are key to business and the social priorities that are central to public authorities and local authorities.

Examples of public-private partnerships at the regional level, in the South of Ukraine, are provided. It is shown, that a public-private partnership is a necessity for evolving public interests, at the country and at the region's level.

Keywords: public-private partnership, interests of social groups, local self-government bodies, business socialization, regional level.

\section{Received: 06.03.2019}

\section{References}

1. Hrytsenko, L.L, I. I. Rekunenko (2014). Derzhavno-pryvatne partnerstvo yak forma aktyvizatsii vzaiemodii derzhavy ta biznesu [Public-Private Partnership as a Form of Enhancing the Interaction of the State and Business] / Visn. Sum. derzh. un-tu. Ser. Ekonomika. Vol.3. - p. 60-70. [in Ukrainian]. 
2. Dosvid ta perspektyvy vprovadzhennia derzhavno-pryvatnykh partnerstv v Ukraini ta za kordonom (2008) [Experience and perspectives of the implementation of public-private partnerships in Ukraine and the currencies]/ B. Vynnytskyi, M. Lendel, B. Onyshchuk, P. Sehvari. - Kyiv.[in Ukrainian].

3. Derzhavno-pryvatne partnerstvo [Public-Private Partnerships].Retrieved from: http://mtu.gov.ua/content/proekt-koncesii-dp-stividornakompaniya-olviya.html

4. Deiaki pytannia orhanizatsii zdiisnennia derzhavno-pryvatnoho partnerstva : Postanova Kabinetu Ministriv Ukrainy vid 11 kvitnia 2011 r. \# 384 [Some issues of the organization of the implementation of public-private partnership]: Postanov Cabinet of Ministers of Ukraine of April 11, 2011, No. 384. - Retrieved from: http://zakon.rada.gov.ua/cgibin/laws/main.cgi

5. Dovidnyk orhanizatsii, proektiv ta prohram mizhnarodnoi tekhnichnoi dopomohy: (pidhot. Prohramoiu USAID RADA: vidpovidalnist, pidzvitnist, demokrat. parlament. Predstavnytstvo) (2017). [Directory of International Technical Assistance Organizations, Projects and Programs: (Prepared by USAID RADA: Responsibility, Accountability, Democrat, Parliament, Representation)] - Kyiv [in Ukrainian].

6. Zapatrina I. V. (2010). Publichno-pryvatne partnerstvo v Ukraini: perspektyvy zastosuvannia dlia realizatsii infrastrukturnykh proektiv i nadannia publichnykh posluh [Public-Private Partnership in Ukraine: Prospects for Implementation of Infrastructure Projects and Public Services Provision ] / I. V. Zapatrina // Ekonomika i prohnozuvannia. - Vol.4. - p. 62-86.

7. Zrazok sprotyvu profspilok proty formuvannia DPP. [A sample of resistance of trade unions against the formation of PPP] - Retrieved from: http:// www.opseu.org/campaign/p3/P3index.

8. Karpa M. I. (2017) Mistse ta rol derzhavno-pryvatnoho partnerstva $\mathrm{u}$ vykonanni funktsii publichnoi sluzhby [The place and role of public-private partnership in the performance of the functions of the public service] / M. I. Karpa // Visn. NAPA. - 2017. - \# 2. - S. 95-103. [in Ukrainian].

9. Moskalenko O. M. Sotsialno-ekonomichni rezultaty tekhnolohichnoho derzhavno-pryvatnoho partnerstva u sviti ta problemy yoho vykorystannia $\mathrm{v}$ Ukraini [Socio-economic results of technological public-private partnership in the world and problems of its use in Ukraine ]/ O. M. Moskalenko // Ekon. teoriia. - Vol. 4. - p. 15-25.[in Ukrainian].

10. Nykyforuk O. I. (2018). Derzhavno-pryvatne partnerstvo: instytutsionalne seredovyshche dlia rozvytku ta modernizatsii infrastruktury Ukrainy [Public-Private Partnership: Institutional Environment for the 
Development and Modernization of Ukraine's Infrastructure] / O. I. Nykyforuk, Yu. V. Husiev, L. Yu. Chmyrova // Ekonomika i prohnozuvannia. - Vol.3. - p. 79-101. [in Ukrainian].

11. Pavlov V. I. (2015)/ Derzhavno-pryvatne partnerstvo v innovatsiinii sferi : monohrafiia [Public-Private Partnership in the Innovation Sector: Monograph ]/ V. I. Pavlov, O. O. Liakhovych; red.: V. I. Pavlov; Spilka ekonomistiv Ukrainy, Akad. ekon. nauk Ukrainy, Nats. un-t vod. hosp-va ta pryrodokorystuvannia, DU "In-t rehion. doslidzh. im. M.I. Dolishnoho NAN Ukrainy". - Rivne : NUVHP, 2015. - 187 p. [in Ukrainian].

12. Panikar H. Yu. (2011) Derzhavno-pryvatne partnerstvo: zarubizhnyi dosvid ta mozhlyvosti yoho vykorystannia dlia Ukrainy [Public-Private Partnership: Foreign Experience and Possibilities for Its Usage for Ukraine] / H. Yu. Panikar // Stratehiia rozv. Ukrainy. - Vol 3. - p. 104-109. [in Ukrainian].

13. Pakhomova T. I. (2012). Derzhavno-pryvatne partnerstvo yak forma vzaiemodii vlady ta biznesu : konspekt lektsii [Public-private partnership as a form of interaction between government and business: a summary of lectures] / T. I. Pakhomova, N. V. Pirozhenko; ORIPA. - Kyiv : NADU, - 54 p. [in Ukrainian].

14. Posibnyk $\mathrm{z}$ monitorynhu ta otsiniuvannia prohram rehionalnoho rozvytku (2007) [Guidance on monitoring and evaluation of regional development programs] /Lendel M., Vynnytskyi B., Rateichak Yu., Sanzharovskyi I./ Za red. Sanzharovskoho I., Polianskoho Yu. - K.: K.I.S. -80 p.[in Ukrainian].

15. Pro derzhavno-pryvatne partnerstvo [For Public-Private Partnership]: (n.d.) zakon.rada.gov.ua. Retrieved from: http://zakon.rada.gov.ua/laws/show/2404-17

16. Rozvytok pidpryiemnytstva $\mathrm{v}$ rehioni : navch. posib. (2010) [Development of entrepreneurship in the region: training. Manual] / red.: V. M. Vakulenko, M. K. Orlatyi; Nats. akad. derzh. upr. pry Prezydentovi Ukrainy. Kyiv - 214 p. [in Ukrainian].

17. Rudenko-Sudarieva L. V. (2017). Derzhavno-pryvatne partnerstvo: teoretychni ta rehuliatorno-instytutsionalni osnovy [Public-Private Partnerships: Theoretical and Regulatory-Institutional Foundations] / L. V. RudenkoSudarieva, O. M. Mozghovyi, K. S. Pashynska; DVNZ "Kyiv. nats. ekon. un-t im. V. Hetmana". - Kyiv : KNEU. - 135 p. [in Ukrainian].

18. Sliusarenko V. Ye. (2015). Stanovlennia instytutu trystoronnoho partnerstva derzhavy - biznesu - "tretoho sektoru" ta yoho vplyv na rozvytok efektyvnoho suspilstva [The formation of the institute of the state-business trilateral partnership - the "third sector" and its influence on the development of an effective society] / V. Ye. Sliusarenko // Visn. Sum. derzh. un-tu. Ser. Ekonomika. -Vol 2. - p. 48-57. [in Ukrainian]. 
19. Solodarenko M. (2015). Sutnisno-teoretychni pidkhody do rozuminnia katehorii derzhavno-pryvatne partnerstvo [Essential-Theoretical Approaches to Understanding the Category Public-Private Partnership] // M. Solodarenko // Nauk. visn.. - Vol 3. - p. 156-172. [in Ukrainian].

20. Solodovnik O. O. (2017). Kompleksne otsiniuvannia realizatsii interesiv storin publichno-pryvatnoho partnerstva [Complex assessment of the realization of the interests of the parties of public-private partnership] / O. O. Solodovnik // Problemy ekonomiky. - Vol 2. - p. 132-139.[in Ukrainian].

21. Stratehiia staloho rozvytku: na shliakhu do sylnishoi hromady= Sustainable Development Strategies: building stronger communities: materialy nauk.-prakt. konf., 21 zhovt. 2016 r. / red.: O. V. Porkuian, I. M. Semenenko, D. M. Marchenko, E. V.Potapenko; Skhidnoukr. nats. un-tim. V.Dalia, Luhan. vid-nia Spilky ekonomistiv Ukrainy, NAN Ukrainy, Luhan. fil. In-tu ekon.-prav. doslidzh. - Sievierodonetsk : Vyd-vo Skhidnoukr. nats. un-tu im. V. Dalia. - 313 p. [in Ukrainian].

22. Shevchenko O. Mekhanizmy stymuliuvannia mizhrehionalnoho spivrobitnytstva v Ukraini [Mechanisms of Stimulation of Interregional Cooperation in Ukraine] / O. Shevchenko/ O. Shevchenko. - Retrieved from: http://niss.gov.ua/articles/1056.

23. Shylepnytskyi P. I. (2011). Derzhavno-pryvatne partnerstvo: teoriia i praktyka: monohrafiia [Public-Private Partnership: Theory and Practice: Monograph] / P. I. Shylepnytskyi; NAN Ukrainy, In-t rehion. doslidzh. Chernivtsi, - 454 p.[in Ukrainian].

\section{Відомості про автора / Information about the Author}

Малиновська Наталя Леонідівна: Чорноморський національний університет імені Петра Могили: вул. 68 десантників 10, Миколаїв, 54003, Україна.

Natalia Malynovska: Black Sea National University of Petro Mohyla: 68 Desantnykiv str. 10, Mykolaiv, 54003, Ukraine.

\section{ORCID.ORG/0000-0003-0861-603X}

\section{E-mail: chdunatali@meta.ua}

